\title{
RELATIONSHIP BETWEEN DRUG DEPENDENCE AND ALCOHOL USERS RECEIVING TREATMENT IN A COMMUNITY HEALTH CENTER SPECIALIZING IN ALCOHOL TREATMENT
}

\author{
Larissa Tiburcio Rodrigues do Nascimento ${ }^{1}$, Jacqueline de Souza², Loraine Vivian Gaino ${ }^{3}$
}

\footnotetext{
${ }^{1}$ Undergraduate student, Escola de Enfermagem de Ribeirão Preto at Universidade de São Paulo (EERP/USP). Ribeirão Preto, São Paulo, Brasil. E-mail: larissa.tiburcio.nascimento@usp.br

${ }^{2}$ Ph.D. in Nursing. Professor, EERP/USP. Ribeirão Preto, São Paulo, Brasil. E-mail: jacsouza2003@usp.br

${ }^{3}$ Doctoral student, Programa de Enfermagem Psiquiátrica e Ciências Humanas, EERP/USP. Ribeirão Preto, São Paulo, Brasil. E-mail: lorainegaino@usp.br
}

\begin{abstract}
The aims of this study were: to identify the therapeutic activities of a psychosocial care center specifically for family members, and to consider whether the care offered provided benefits to the relationship between the family and alcohol users. This was a qualitative research study, and included 15 families of alcohol users from Minas Gerais. The data collection occurred during January and March of 2012. Thematic analysis was used. The analysis identified three themes: 1) relationship: before and after the initiation of treatment in the service; 2) assistance for the family; 3) treatment suggestions. The results showed that the care in the service contributed to improving the family relationship, but families provided some suggestions to improve this care. We concluded that the service was an important provider of social support for improving the family relationship.
\end{abstract}

DESCRIPTORS: Family relations. Mental health services. Alcoholism.

\section{RELACIONAMENTO ENTRE FAMILIAR E USUÁRIO DE ÁLCOOL EM TRATAMENTO EM UM CENTRO DE ATENÇÃO PSICOSSOCIAL ESPECIALIZADO}

\begin{abstract}
RESUMO: Os objetivos deste estudo foram: identificar as atividades terapêuticas de um Centro de Atenção Psicossocial, especificamente para os familiares, e analisar se os cuidados oferecidos proporcionam benefícios para a relação entre o familiar e o usuário de álcool. Trata-se de uma pesquisa qualitativa. Foram entrevistados 15 familiares de usuários de álcool de um município de Minas Gerais. A coleta de dados foi realizada entre janeiro e março de 2012. Utilizou-se a análise temática. A análise permitiu identificar três categorias: 1) Relacionamento: antes e depois do início do tratamento no serviço; 2) Assistência ao familiar; e 3) Sugestões ao tratamento. Os resultados evidenciaram que a assistência proporcionada contribuiu na geração de benefícios para a relação familiar. Conclui-se que o serviço consiste numa importante fonte de suporte, proporcionando melhorias às relações familiares.
\end{abstract}

DESCRITORES: Relações familiares. Serviços de saúde mental. Alcoolismo

\section{RELACIÓN ENTRE EL FAMILIAR Y EL USUARIO DE ALCOHOL EN TRATAMIENTO EN UN CENTRO DE ATENCIÓN PSICOSOCIAL DE ALCOHOL Y DROGAS}

RESUMEN: Los objetivos de este estudio fueron identificar las actividades terapéuticas de un centro de atención psicosocial específicamente para los miembros de la familia y considerar si la atención que se ofrece proporciona beneficios a la relación entre los usuarios de la familia y el usuario de alcohol. Se trata de una investigación cualitativa. Se entrevistaron 15 familiares de usuarios de alcohol de Minas Gerais. La recolección de datos se llevó a cabo entre enero y marzo de 2012. Se utilizó el análisis temático. El análisis identificó tres temas: 1) Relación: antes y después del inicio del tratamiento en el servicio; 2) Asistencia para la familia y; 3) sugerencias de tratamiento. Los resultados muestran que la asistencia prestada por el servicio ha contribuido beneficiosamente a la relación de la familia, sin embargo, hubo varias sugerencias realizadas por los familiares con el fin de mejorar la asistencia. Se concluye, por lo tanto, que el servicio funcionaba como una fuente importante de apoyo favoreciendo la relación de familia.

DESCRIPTORES: Relaciones familiares. Servicios de salud mental. Alcoholismo. 


\section{INTRODUCTION}

Alcoholism, as well as the abuse of other drugs, have been described as an important factor related to the increase of morbidity, mortality, interpersonal harm and family dysfunction. ${ }^{1-7}$ The relationship among alcoholism and the family is discussed mainly from two perspectives: a) genetics, behavior, and relational aspects in family context, as a risk factor for substance abuse, ,-3-3,-5-6,-14 $^{-1}$ b) the impact of alcoholism on family relationships. $2,5,7$

The first perspective asserts that families with deficient patterns of communication and those which do not promote support to their members, or those with home, work and income insecurity, as well as situations of negligence, domestic violence and a family member as a substance user, in general provide an environment that is more susceptible to substance related disorders. ${ }^{1,6,8-13}$

Various studies ${ }^{1,6,8-13}$ have prioritized the first perspective, meaning that there is a family influence on the development of drug dependence. The researchers that follow this approach have produced evidence and recommendations to improve the family context as a important strategy to prevent substance-related disorders.

The second perspective is that alcoholism has a negative impact on the family. These authors $2,5,7,15-16$ believe that the consumption of this substance creates worries, negative emotions, tension, conflicts and breakups, in addition to financial and legal problems, risk for clinical and psychopathological disease, behavior problems, traumatic experiences, loss of confidence, deficit of communication, and a trend toward social isolation. $2,5,7,15$

Due to some psychological symptoms such as irritability, aggressiveness, bad comprehension and changes in one's worldview, the alcoholic tends to present progressive difficulties related to interpersonal relationships. ${ }^{17}$

The inconsistency and affective instability of family relationships with their addict member weakens the family structure and promotes the emotional detachment of members, ${ }^{15}$ because, in general their answer to this situation is to develop protective strategies, such as limiting contact with the addicted person or having contact only when necessary. ${ }^{18}$

Some studies about alcoholism ${ }^{16,19-21}$ have characterized the family as an impaired unit, fragmented, deteriorated by frequent conflicts and existential crises; however most often the family members are not well aware of the extension of this psychic suffering. Thus, in the second perspective, the authors recommend the consideration of the family and the drug user as a unit, as a whole, and they add that the success of the treatment for a substance related-disorder is directly related to inclusion of the family in a recovery process aimed at abstinence.

Given these considerations, including the family as part of treatment is a presupposition of Brazilian legislation and guidelines for assistance of substance-related disorder people..$^{22}$ Family activities are included in the Community Health Centers specializing in the treatment of substancerelated disorders in Brazil (CAPSad), as a primary strategy in the routine treatment of patients. ${ }^{22-23}$

These guidelines recommend that professionals from this service do a progressive therapeutic planning for each patient following an interdisciplinary review, including various activities as individuals (medication, psychotherapy, advices and others) as well as through therapeutic groups and workshops, home visits, and psychosocial family assistance. ${ }^{22}$

Considering that the alcoholism can promote negative changes in interpersonal relationships between the individual and society, and that assistance offered by CAPSad should include this assistance, it is understood that the improvement of relationships in the family context can be an important outcome indicator of the mental health assistance promoted by CAPSad. Thus, the guiding question is proposed: how does the assistance offered by this service influence the relationship between family members and alcoholics under treatment?

Thereby, this study aims to identify the therapeutic activities from CAPSad, specifically in regard to the family; and to analyze whether this assistance provided a benefit for the relationship between the family and the alcohol addict.

\section{METHOD}

This was a qualitative, descriptive, crosssectional study performed in a CAPSad in Minas Gerasi, Brazil. In the beginning, one of the researchers participated in four family meetings promoted by this service. In the last meeting, she presented the proposal of this research to these families, and they were formally invited to participate in this study. 
The inclusion criteria for selection of participants were: having a family member in treatment in this CAPSad with an alcoholism diagnosis, participating in at least one monthly family meeting promoted by this service, and being greater than 18 years old. The 15 family members invited met these inclusion criteria, and agreed to participate in this study.

During the period of January until March of 2012, domiciliary visits were performed along with semi-structured interviews for data collection. An interview guide was used with content about socio-demographic data, the family relationship during the process of the addiction, and assistance offered to the family by CAPSad. The interviews lasted about one hour, and were recorded and transcribed. To preserve the anonymity of the participants, the transcriptions were coded with the letter F, that signified "family", and with a number related to each participant and the degree of relationship, for example: "F1-father".

For data analysis, the theoretical perspective on the impact of alcoholism in family relationships was adopted, based on bibliographical references about alcoholism: which aspects of these relationships are affected, what are the behavior changes of the members, what are the changes and psychological repercussions on family by relating to the alcoholic person. ${ }^{2,5,7,15,19-21}$

The first step of the analysis was to describe the profile of participants, and the second was the thematic analysis that is a genre of content analysis. The transcripts of interviews were successively read in order to cluster common elements, ideas or expressions from the interviews. In this interpretative phase, a kind of chronologic sequence in the data was identified, then a grouping of information occurred, highlighting how the relationship was of the family before and after the psychosocial treatment. From this group of information, the interventions were identified from CAPSad, described by family along with their suggestions about them. Thus, three thematic categories were created:1) Relationship: before and after beginning treatment at the CAPSad 2) Family assistance, and 3) Treatment suggestions offered by CAPSad. The next phase was theory building; the researchers crossed the information of the present study with the outcomes of previous studies developed using the same theoretical perspective adopted in this one. ${ }^{24}$

The Ethics Committee of the Escola de Enfermagem de Ribeirão Preto, Universidade de São Paulo (CEP-EERP/USP 011/2012), approved this study. The ethical principles were attended to, and the Terms of Free and Informed Consent swas used.

\section{RESULTS}

Regarding the sociodemographic characteristics of the family members, the majority were female (10 participants, $66 \%$ ) with a mean of 50 years old (minimum 21 and maximum 80 years old), as shown in Table 1. According to interviews, 11 of the family members in treatment had already received assistance from other services before, and they met CAPSad through health professionals, colleagues or relatives.

Table 1 - Socio-demographic data from those interviewed. Minas Gerais, 2012

\begin{tabular}{|c|c|c|c|c|c|}
\hline $\begin{array}{c}\text { Participant and } \\
\text { parenthood }\end{array}$ & $\begin{array}{c}\text { Time of treatment of } \\
\text { addict }\end{array}$ & Age & Gender* & $\begin{array}{l}\text { Monthly family income } \\
\text { (minimum wage) }\end{array}$ & Marital status \\
\hline F1-Father† & 15 days & 66 & $\mathrm{M}$ & $3-5$ & Married \\
\hline F2-Father $\ddagger$ & 1 month & 55 & M & $1-2$ & Single \\
\hline F3-Wife & 1 month and 15 days & 34 & $\mathrm{~F}$ & $1-2$ & Married \\
\hline F4-Wife & 2 months & 49 & $\mathrm{~F}$ & $1-2$ & Married \\
\hline F5-Girlfriend§ & 2 months & 39 & $\mathrm{~F}$ & $3-5$ & Single \\
\hline F6-Mother† & 4 months & 80 & $\mathrm{~F}$ & $1-2$ & Married \\
\hline F7-Son || & 4 months & 21 & M & $3-5$ & Single \\
\hline F8-Girlfriend | | & 4 months & 35 & $\mathrm{~F}$ & $3-5$ & Single \\
\hline F9-Brother§ & 8 months & 68 & M & $1-2$ & Married \\
\hline F10-Husband§ & 8 months & 49 & M & $3-5$ & Married \\
\hline F11-Mother† & 1 year & 64 & $\mathrm{~F}$ & $3-5$ & Widowed \\
\hline F12-Wife† & 1 year & 40 & $\mathrm{~F}$ & $1-2$ & Married \\
\hline F13-Sister $\ddagger$ & 1 year & 52 & $\mathrm{~F}$ & $1-2$ & Stable union \\
\hline F14-Mother & 2 years & 62 & $\mathrm{~F}$ & $1-2$ & Married \\
\hline F15-Sister† & 2 years & 39 & $\mathrm{~F}$ & $3-5$ & Married \\
\hline
\end{tabular}

${ }^{*} \mathrm{M}=$ Male, F=Female; †Participant with incomplete elementary school; $\ddagger$ Participant completed elementary school; §Participant completed high school; | | Participant with incomplete high school; $\mid$ Participant illiterate. 
The data analysis allowed the identification of three thematic categories: 1) Relationship: before and after beginning treatment at the CAPSad; 2)
Family assistance; and, 3) Treatment suggestion offered by CAPSad, according to Figure 1.

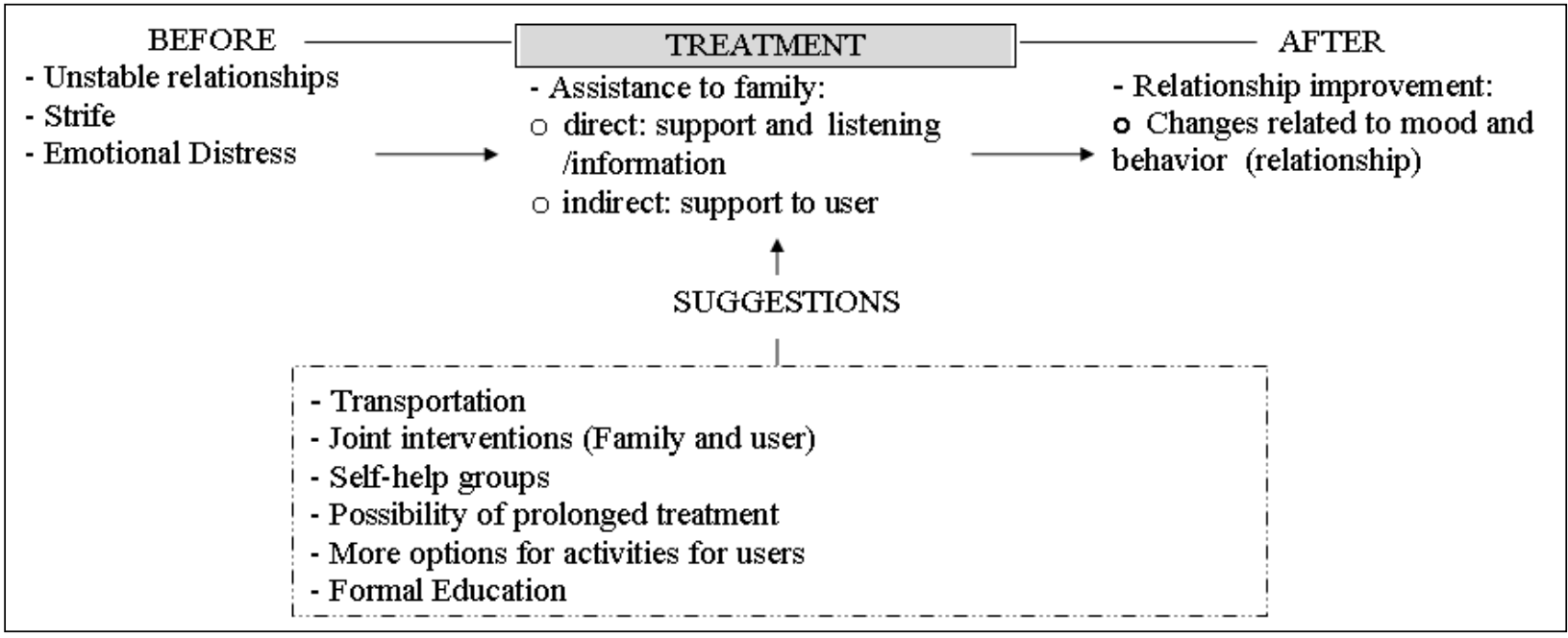

Figure 1 - Thematic categories related to family and user relationships

\section{Relationships: before and after beginning treatment at the CAPSad}

The majority of family members expressed that their relationship was unstable and conflicted before the alcoholic began treatment at the CAPSad; they mentioned emotional distress, strife and strained relationships.

Just a couple of those individuals interviewed described the existence of respectful relationships, even before treatment. Nevertheless, all those interviewed mentioned an improvement in relationships with the user after he/she began treatment at the CAPSad, and some affirmed that the user now had a quieter behavior.

God! It was a terrible life, I don't like to remember, terrible even [...] There was a lot of strife between us and his family [...].After his treatment began he changed a lot, he had other thoughts (F4-wife).

I was blackmailing her, I didn't visit her and she called me saying that I was the only one she had, because no one called her, and I told her that if that situation continued, she wouldn't actually be able to count on me either, because I'd stop worrying about her (F13-sister).

After his treatment began he was more quiet, you know? We are living much better; everything is calmer, now we have more conversation to solve the things [...] even his behavior at home, his mood changed, he is more fun and willing [...] (F12-wife).

\section{Assistance to family}

With regard to the family assistance offered by CAPSad, the participants mentioned professional support, opportunities to express themselves, and being listened to during the meetings that occurred in this service with professionals and family members. Some participants referred to difficulties participating in these meetings because of schedule conflicts, it meaning, the days and hours of the meetings were the same as for their jobs.

The support offered to users by CAPSad also was mentioned as a kind of indirect family assistance, because of the benefits related to the relationship between them.

Here I have all the structure that I need, the trust that I need to know that treatment is really good for him. I think this service is one of the best things, the freedom that we have to come and express what is happening, and trust in the work of these professionals (F12-wife).

All that they do for him [user] they are doing for us, too. When the CAPSad takes care of him, it is taking care of the family (F9-brother).

They offer support, have meetings [...], but for me, it is difficult to go there because of my job (F7-son).

\section{Treatment suggestions}

There were many suggestions to improve the assistance offered by CAPSad, for example: 
availability of transportation; possibilities for participating in joint meetings with professionals and the user; and, inviting recovering alcoholics to share their history with users. Many family members gave other suggestions, although they expressed satisfaction with all assistance offered by CAPSad.

If there was some transportation, like a bus, it could be easier. It could be interesting also for him and me to talk with some professional together (F4-wife).

In addition, to invite people that had this experience before, that re recovering and aren't currently drinking, to give advice to users. Then, people that had treatment at CAPSad, could go back there to help those that are in treatment (F7-son).

If it was possible for them to stay there, it could be easier than them coming back home [...] then I think that if it was possible to accommodate all of them there for about six months, it could be easier for these people to recover (F1-father).

[...] I think that it could be good for her to study, because she does not have a lot of knowledge, she writes, but cannot read [...]. Then I think that if she could learn to read, she could participate more in the life activities of her son [...], I would also like to have something to help her stop smoking, because she smokes a lot (F13-sister).

[...] Could be better if he could keeping attending the CAPSad at least twice per week, because I heard that he is well and that soon he will be discharged, but I think that he should keeping attending at least twice per week (F14-mother).

\section{DISCUSSION}

According to the results, the participants have a lower educational level and monthly income below two minimum wages, corroborating the current literature that highlights these conditions as risk factors for the impact of alcoholism. ${ }^{25-30}$ With regard to the prevalence of the female gender among the family members that accompany the alcoholism treatment of their loved one, the results also are similar to previous research. ${ }^{16,31}$

Related to time of treatment, according to Table 1, this was between 15 days and two years; of the 15 participants, ten were in treatment for less than one year. Studies show that only $25 \%$ of people that use alcohol excessively ask for some kind of help. This low demand is related to stigma and therapies that are different than what is needed by the patient. Another challenge is that only a low percentage of patients adhere to treatment, culminating in an abandonment index of about $20 \%$. Thus, it is recommended to use strategies to improve the family relationships as a focus for maintaining and completing treatment. ${ }^{19-21}$

Related to the first category, the participants pointed out that daily life with the alcoholic family member was characterized by instability, strife and worries that resulted in physical and emotional distress, beyond shameful situations, constraints and humiliation for the family as well as for the alcoholic, corroborating previous results. $5,7,15,18,21$

According to some participants, the feeling of impotence when confronting addiction of a family member is common, however information about alcoholism and the treatment process can help with more effective management of conflicts, and strengthen interpersonal relationships beyond the avoidance of withdrawal from social life. ${ }^{7}$

A study developed with relatives of alcoholic individuals shows that receiving information and advice about how to help the alcoholic family member are the main needs related to treatment. The lack of knowledge about medication side effects is an important difficulty that creates feelings of stress, isolation, depression, low self-esteem and anger among family members. ${ }^{21}$ In addition, the patterns of communication in these contexts are not clear, with pejorative expressions and difficulty establishing limits; therefore, advice for improving the relationship and decision-making is important. ${ }^{15}$

One specific piece of data found in this research that is discordant of descriptions in the current literature is that some families mentioned not having any problems in their relationships with the alcoholic family member before treatment, despite the fact that the alcohol use was already happening. The difficulty pointed out by these participants was seeing the condition of addiction that was causing suffering in their family member.

The results of this study show that, after beginning treatment, CAPSad was configured as space promoting the self-knowledge of users, generating an important impact on family relationships. The participants mentioned that, after beginning treatment, the users showed changes in their thinking, new life plans, friendships, strengthening of social and affective links with family, better mood, dialogue, more skill in listening, and diminishment of responding to impulses. It was also cited that CAPSad provided leisure and occupied times of idleness. Thus, it is considered that this service provides a potent mechanism that helps to amplify and reconfigure the social support network of the alcoholic. ${ }^{31-33}$ 
With regard to category two, researchers who recommended interventions for the family during the treatment of alcoholics have affirmed that it is important to offer many options for assistance, such as: approaches to resolve family conflicts, and treatment related to drug addiction for other family members. ${ }^{1,19}$ In addition, other recommendations include: being available to give informational support, psychoeducational activities, social support groups, strategies to improve quality of life of these families, encourage open discussions about the alcoholic family member's behavior, provide opportunities to express feelings and share personal experiences. ${ }^{7,15,21}$

In the present study, some of these interventions were pointed out. Additionally, to value the treatment of the user, the participants demonstrated appreciation of the care that CAPSad provided to them, and cited many benefits generated in the relationship between the user and the family members.

The participants explained the indirect benefits from the treatment; meaning that the recovery of the alcoholic individual impacts the relationships with the family. They also mentioned that the CAPSad's team welcomed the needs of the family, providing enlightenment, guidance and assistance when it was needed. These interventions contributed their tearning about how to deal with situations that, in the past, could lead the user to psychiatric hospitalization, and this result was corroborated by other studies. ${ }^{19-21,34}$

The participants mentioned the freedom to express themselves, discuss and be heard - giving a positive evaluation about the treatment model proposed as a substitute to the psychiatric centered model. It motivated families to take a participatory stance in CAPSad and in the treatment of their loved one, contributing to the improvement of the operation of this service and the adjustment to the family context.

The restriction on the schedule of family meetings provided by the service was a negative aspect cited in this study about the care provided to the family. These meetings occur only on Fridays during mornings and afternoons. Considering that many family members work during these times, the CAPSad should offer some assistance during the evening hours whenever possible and necessary, following the recommendations about the operation of CAPSad from Ministry of Health guideline, ${ }^{35}$ this could provide more opportunities for families to participate in treatment.
The participants perceived positive changes in the relationships with the user after beginning treatment at CAPSad; however, according to results from the third category, many suggestions were made about operation of this service. For example, enabling transportation, because the geographic access to these service is not easy from downtown. This result corroborates with a previous study with families of alcoholics in the United States, that demonstrated transportation difficulties were a main factor related to users leaving treatment. ${ }^{21}$

Another suggestion from participants was for CAPSad to provide joint interventions with the family, professionals and users. This result also was shown in a previous study in the United Kingdom that recommended this kind of intervention as an important strategy for the maintenance of treatment. ${ }^{7,36}$

The suggestion that recovering alcoholics share their experience with users in treatment is consistent with the Alcoholics Anonymous proposal, and it is possible to put it in practice at CAPSad; this provides possibilities for members to help each other, share their experiences of suffering and history of recovery, which are strategies compatible with the proposal of this service.

The statements of some family members suggesting that CAPSad provide hospitalization for a long period demonstrated a lack of understanding about the philosophy of this service, maybe due to their being with their user only a few times for treatment, or due the proposal of this service not being well clarified. This highlights the importance of providing clarification about the activities, philosophy and operation of the community-based service at the beginning of treatment, explaining the difference between what is offered in an inpatient and an outpatient services that, according to the Psychiatric Reform Law, have as a principle an "open doors" operation, avoiding isolation of the user from his social life..$^{21,37}$

To attend the suggestions about offering more activities, such as workshops or more formal education, treatment for smoking cessation, and groups for maintaining abstinence after patient discharge, it is necessary for CAPSad to involve multiple sectors in this operation, including other healthcare, educational and social protection providers from the territory. ${ }^{35}$

\section{CONCLUSION}

It follows that CAPSad generates many benefits to relationships between the family and the 
user. The relationships prior to beginning treatment were highlighted by instability, becoming in a step by step fashion, respectful relationships based on user self-knowledge and self-control.

The participants mentioned the family meeting as an informational support source and an opportunity for being heard. In addition, they highlighted indirect benefits for the family from treatment provided to their loved one, as well as direct benefits from assistance provided by CAPSad, specifically for the family. It is understood that the activities mentioned by participants are minimal, if we compare them with the recommendations from the scientific literature and current public policy.

Thus, the results from this study have operational implications related to reinforcement of the need of amplify the therapeutic activities from community-based mental health services targeted to families, enhancing the assistance for collaborating with families to enable them to feel more supported and to better understand the problem faced by the user. Certainly these can contribute to the maintenance of a participatory stance by the family on the treatment of its loved one, also contributing to adherence of his own treatment.

The relevance of the families' suggestions and recommendations from the data analyzed are important highlights. It requires the need of multi-sectorial actions related to health, education and social protection, self-help groups similar to Alcoholics Anonymous, alternative schedules and explanation to family members about the philosophy and operation of the service. These actions could contribute to more effective assistance for the user and his family, resulting in an even more prosperous relationship for them both.

In addition, it is important to think about the competence of nursing professionals, enabling strategies to integrate the different knowledge fields to improve group interventions, facilitation of informational support, as well as administrative flexibility of the work operation in health services. Putting these competences into practice in a multi-professional team could surely amplify the effectiveness of these services.

This study is limited to the family members' perception about treatment and relationships, so a larger study that could also consider the users' and professionals' perceptions could certainly enable effective cross-information, and a more extensive analysis of the real benefits related to assistance provided by CAPSad on the relationship of the family members with the user receiving treatment.

\section{REFERENCES}

1. Surkan PJ, Fielding-Miller R, Melchior M. Parental relationship satisfaction in French young adults associated with alcohol abuse and dependence. Addict Behav. 2012 Mar; 37(3):313-17.

2. Oliveira EB, Mendonça JLS. Family members with chemical dependence and consequent overburden suffered by family: descriptive research. Online Braz J Nurs [online]. 2012 [acesso 2013 Out 7];11(1):14-24. Disponível em: http://www. objnursing.uff.br/index.php/nursing/article/ view/3480/html_1

3. Laranjeira R, Madruga CS, Pinsky I, Caetano R, Ribeiro M, Mitsuhiro S. II Levantamento Nacional de Álcool e Drogas - Consumo de Álcool no Brasil: Tendências entre 2006/2012 [página na internet]. São Paulo (SP): INPAD; 2013 [atualizado 2013; acesso em 2013 Out 7]. Disponível em: http://inpad.org.br/ wp-content/uploads/2013/04/LENAD_ALCOOL_ Resultados-Preliminares.pdf

4. Jackson C. Families in trouble. Ther Today. 2012 Set; 23(7):8-11.

5. Benishek LA, Kirby KC, Dugosh KL. Prevalence and Frequency of Problems of Concerned Family Members with a Substance Using Loved One. Am J Drug Alcohol Abuse. 2011 Mar; 37(2):82-8.

6. Lemos VA, Antunes HKM, Baptista MN, Tufik S, Mello MT, Formigoni MLOS. Low Family support perception: a 'social maker' of substance dependence?. Rev Bras Pisquiatr. 2012 Mar; 34(1):52-9.

7. Templeton, L. Use of a structured brief intervention in a group setting for family members living with substance misuse. J Subst Use. 2009; 14(3/4):211-20.

8. Weiss JW, Merrill V, Akagha K. Substance use and its relationship to family functioning and self-image in adolescents. J Drug Educ. 2011; 41(1):79-97.

9. Knudson TM, Terrell HK. Codependency, perceived interparental conflict, and substance abuse in the family of origin. Am J Fam Ther. 2012; 40(3):245-57.

10. Taf ${ }^{\prime} A M$, Baiocco R. Addictive behavior and family functioning during adolescence. Am J Fam Ther. 2009; 37(5):388-95.

11. Vasquez M, Meza L, Almandarez O, Santos A, Matute RC, Canaca LD, et al. Evalution of strengthening families (Familias Fuertes) intervention for parents and adolescents in Honduras. South Online J Nurs Res [online]. 2010 [acesso 2013 Out 7]; 10(3). Disponível em: http://www.resourcenter.net/images/snrs/ files/sojnr_articles2/Vol10Num03Art01.pdf

12. Windle $\mathrm{M}$, Windle RC. Intergenerational relations for drinking motives: invariant for same- and opposite-sex parent-child dyads?. J Stud Alcohol Drugs. 2012 Jan; 73(1): 63-70.

13. Ichiyama MA, Fairlie AM, Wood MD, Turrissi R, Francis DP, Ray AE, et al. A randomized trial of a parent-based intervention on drinking behavior 
among incoming college freshmen. J Stud Alcohol Drugs Suppl. 2009 Jul; (16):67-76.

14. Silva SED, Padilha MI. O alcoolismo na história de vida de adolescentes: uma análise à luz das representações sociais. Texto Contexto Enferm [online]. 2013 Jul-Set [acesso 2013 Out 7]; 22(3):576-84. Disponível em: http://www.scielo. br/scielo.php? script $=$ sci_arttext\&pid $=$ S010407072013000300002\&lng=en

15. Nunes de Miranda FA, Simpson CA, Azevedo DM de, Costa SDS. O impacto negativo dos transtornos do uso e abuso do álcool na convivência familiar. Rev Eletr Enferm [online]. 2009 Aug 28 [acesso2014 Jul 14];8(2). Available from: http://h200137217135. ufg.br/index.php/fen/article/view/7037

16. Seadi SMS, Oliveira MS. A terapia multifamiliar no tratamento da dependência química: um estudo retrospectivo de seis anos. Psicol Clin. 2009; 21(2):363-78.

17. Beck LM, David HMS. O abuso de drogas e o mundo do trabalho: possibilidades de atuação para o enfermeiro. Esc Anna Nery. 2007 Dez; 11(4):706-11.

18. Jackson LA, Dykeman M, Gahagan J, Karabanow J, Parker J. Challenges and opportunities to integrating family members of injection drug users into harm reduction efforts within the Atlantic Canadian context. Int J Drug Policy. 2011 Set; 22(5):385-92.

19. Escribanoa JJA, Martínb MM, Encinasb IP, Guzmánb FJL. Tratamiento de la dependência del alcohol. Medicine. 2012;11(23):1412-20.

20. O’Farrell TJ, Murphy M, Alter J, Fals-Stewart W. Behavioral family counseling for substance abuse: a treatment development pilot study. Addict Behav. 2010 Jan; 35:1-6.

21. EnglandKennedy ES, Horton S. "Everything that I thought that they would be, they weren't:" Family systems as support and impediment to recovery. Soc Sci Med. 2011 Out; 73(8):1222-9.

22. Ministério da Saúde (BR). Secretaria de Atenção à Saúde, SVS/CN-DST/AIDS. A política do Ministério da Saúde para atenção integral a usuários de álcool e outras drogas. Brasília (DF): MS; 2004.

23. Brasil. Lei n.3.088, de 23 de dezembro de 2011: institui a Rede de Atenção Psicossocial para pessoas com sofrimento ou transtorno mental e com necessidades decorrentes do uso de crack, álcool e outras drogas, no âmbito do Sistema Único de Saúde. Diário Oficial da União, 30 Dez 2012. Seção 1.

24. Minayo MCS. O desafio do conhecimento: pesquisa qualitativa em saúde. São Paulo (SP): Hucitec; 2007.

25. Primo NLNP, Stein AT. Prevalência do abuso e da dependência de álcool em Rio Grande (RS): um estudo de base populacional. Rev Psiquiatr Rio Gd Sul. 2004 Set-Dez; 26(3):280-6.

26. Costa JSD, Silveira MF, Gazalle FK, Oliveira SS, Hallal PC, Menezes AMB, et al. Heavy alcohol consumption and associated factors: a population-based study. Rev Saúde Pública. 2004 Abr; 38(2):284-91.

27. Baumann M, Spitz E, Guillemin F, Ravaud JF, Choquet M, Falissard B, et al. Associations of social and material deprivation with tobacco, alcohol, and psychotropic drug use, and gender: a populationbased study. Int J Health Geogr. 2007 Nov 9; 6:50-62.

28. Moreira MM, Galera SAF. Evaluación del uso de alcohol por familias de la periferia de Guayaquil en Ecuador, por estudiantes de enfermería. Rev LatinoAm Enfermagem. 2010; 18(Esp):620-5.

29. Mulia N, Zemore SE. Social adversity, stress, and alcohol problems: are racial/ethnic minorities and the poor more vulnerable? J Stud Alcohol Drugs. 2012 Jul; 73(4):570-80.

30. Oliva AL. Apoio social para dependentes do álcool [tese]. Ribeirão Preto (SP): Universidade de São Paulo. Programa de Pós-Graduação em Saúde na Comunidade; 2007.

31. Vargas NIT, Zago MMF. El sufrimiento de la esposa en la convivência com el consumidor de bebida alcohólicas. Rev Latino-Am Enfermagem. 2008; 13(Esp):806-12.

32. Souza J, Kantorski LP, Mielke FB. Vínculos e redes sociais de indivíduos dependentes de substâncias psicoativas sob tratamento em CAPS AD. SMAD, Rev Eletrônica Saúde Mental Álcool Drog [online]. 2006 [acesso 2012 Jun 20]; 2(1):1-17. Disponível em: http://http://www.revistasusp.sibi.usp.br/pdf/ smad/v2n1/v2n1a03.pdf

33. Jahn AC, Rossato VMD, Oliveira SS, Melo EP. Grupo de ajuda como suporte aos alcoolistas. Esc Anna Nery. 2007 Dez; 11(4):645-9.

34. Moreno V. Familiares de portadores de transtorno mental: vivenciando o cuidado em um CAPSad. Rev Esc Enferm USP. 2009 Set; 43(3):566-72.

35. Ministério da Saúde (BR). Secretaria de Atenção à Saúde. Saúde mental no SUS: os centros de atenção psicossocial. Brasília (DF): MS; 2004.

36. White WL. The mobilization of community resources to support long-term addiction recovery. J Subst Abuse Treat. 2009 Mar; 36(2):146-58.

37. Brasil. Lei n.10.216, de 6 de abril de 2001: dispõe sobre a proteção e os direitos das pessoas portadoras de transtornos mentais e redireciona o modelo assistencial em saúde mental. Diário Oficial da União, 9 Ab. 2001. Seção 1. 